\title{
Correction to: Reimagining US Colombianidades: Transnational subjectivities, cultural expressions, and political contestations
}

\section{Lina Rincón ${ }^{1}$ · Johana Londoño ${ }^{2}$ • Jennifer Harford Vargas ${ }^{3}$. María Elena Cepeda ${ }^{4}$}

Published online: 28 September 2020

(c) Springer Nature Limited 2020

\section{Correction to: Latino Studies (2020) 18:301-325 https://doi.org/10.1057/s41276-020-00271-7}

Due to an unfortunate oversight a mistake occured in the reference section.

The reference

Aparicio, A. 2017. Latinidad. In Keywords for Latina/o Studies, ed. D.R. Vargas, N.R. Mirabal, and L. La Fountain-Stokes. New York: New York University Press.

\section{Should be read as}

Aparicio, F. 2017. Latinidad. In Keywords for Latina/o Studies, ed. D.R. Vargas, N.R. Mirabal, and L. La Fountain-Stokes. New York: New York University Press.

The original article can be found online at https://doi.org/10.1057/s41276-020-00271-7.

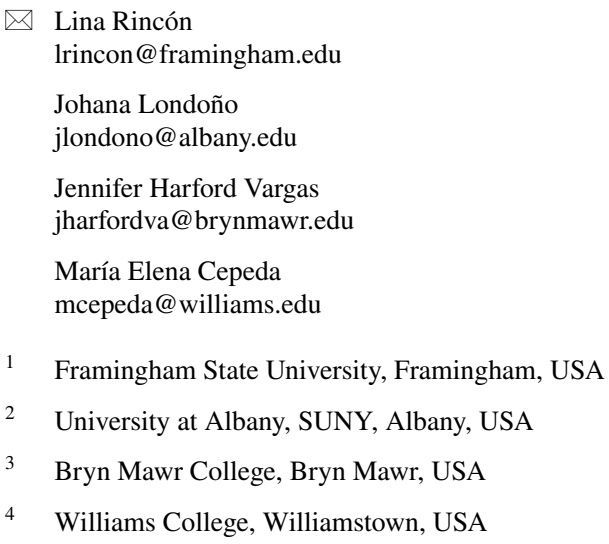


Publisher's Note Springer Nature remains neutral with regard to jurisdictional claims in published maps and institutional affiliations. 